\title{
In memoriam B. Loty
}

\author{
C. Delloye
}

Received: 5 July 2010/Accepted: 6 July 2010/Published online: 15 July 2010

(C) Springer Science+Business Media B.V. 2010

EAMST (European association of Muskulo-Skeletal Transplantation) is sad to announce the death of Dr Bernard Loty (1953-2010) who has passed away on June 7, 2010 after a long fight with disease.

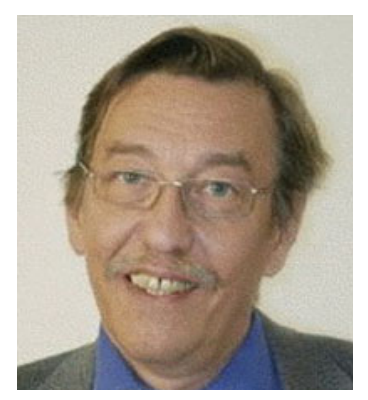

While being registrar in the department of orthopaedic surgery of Professor Tomeno at Cochin hospital in Paris, Bernard Loty got a major interest in bone banking activities. He established in this hospital a bone bank. He also founded the GESTO, a French group dealing with bone grafts and substitutes. He chaired this organization from 1990 to 1995.
In 1994, he was offered and accepted to become medical director of the Etablissement Français des Greffes where he organized the field of human tissue transplantation, setting clear guidelines. He communicated largely on this field in many professional meetings. He was frank and human. Hard worker, he always tried to gradually bridge divergent points of view. Reaching an effective consensus was always his goal and often he was successful.

In the late 1990's, he became more involved in European administration in transplantation and played a vital role in the formation of the EU Directive on Tissue Cell and Gametes which is now used to regulate activities in this area across Europe. In 2005 Bernard Loty became Medical Director and Assistant Executive Director of the Biomedicine Agency in France.

He was married to Dominique Loty, Lawyer and was father of four children. EAMST offers its condolences to Dominique and her children and commemorates his significant input into European transplantation.
C. Delloye $(\bowtie)$

St Luc Clinical University, Brussels, Belgium

e-mail: christian.delloye@uclouvain.be 